\title{
GADD45B Gene
}

National Cancer Institute

\section{Source}

National Cancer Institute. GADD45B Gene. NCI Thesaurus. Code C105844.

This gene plays a role in signaling, apoptosis and cell growth. 